\title{
Alienação, reificação e fetichismo da mercadoria
}

\author{
Anselm Jappe \\ (Tradução: Sílvio Rosa Filho; Revisão: Jacira Freitas)
}

Resumo: O presente artigo analisa as categorias de alienação e reificação, baseando-se nas análises marxianas do fetichismo da mercadoria e do trabalho abstrato. Retoma, para tal, a recepção destas categorias em alguns autores marxistas no século XX e mostra como estes ficaram prisioneiros de uma ontologia do trabalho que os impediu de compreender que a crítica delas supõe a crítica do papel que o trabalho e o valor desempenham no sistema capitalista. Esta compreensão, presente já na crítica da economia política de Marx, se tornou evidente com a crise real da sociedade do trabalho, principalmente a partir dos anos 1970, e constitui o núcleo das abordagens teóricas dos autores em torno da "crítica do valor" (Wertkritik), como Robert Kurz, Moishe Postone e o autor deste artigo.

Palavras-chave: alienação - reificação - fetichismo - crítica do valor (Wertkritik) - marxismo.

\begin{abstract}
This paper analyzes the categories of alienation and reification based on Karl Marx's reflections on the fetischism of ware and abstract work. It resumes the reception of these categories by some Marxists thinkers of $20^{\text {th }}$. Century and shows that these were prisoners of an ontology of work, which hinders them to comprehend that the critic of those categories supposes the critic of the role played by work and value in capitalism. This comprehension, that can be found in Marx's critic of political economy of Marx, became evident during the crisis of the work society particularly since 1970 and composes the core of theoretical approaches of the authors around the "value's critics" (Wertkritik) such as Robert Kurz, Moishe Postone und the author of this article.

Keywords: alienation - reification - fetishism - value's critics (Wertkritik) - marxism.
\end{abstract}


Nos tempos da Segunda Internacional (1889-1914), a teoria de Marx foi transformada em uma ideologia centrada na "luta de classes" e na reivindicação de uma redistribuição diferente do sobrevalor. Desde então, continuou-se a utilizar as análises de Marx essencialmente com esta meta: obter maior justiça social. Em sua formulação clássica, o sujeito histórico dessas reivindicações correspondia à classe operária, essencialmente assimilada, neste caso, ao proletariado industrial.

Nos últimos decênios tal esquema foi aplicado frequentemente sob nova forma, ao fazer referência a outras figuras da exploração e da dominação (os povos do "Terceiro Mundo", os "subalternos", as mulheres). Pode-se observar entretanto que, em todos esses casos, não é verdadeiramente o conteúdo da reprodução capitalista que está posto em questão, mas antes $\mathrm{o}$ acesso a seus resultados. $\mathrm{O}$ valor e o dinheiro, o trabalho e a mercadoria não são ali concebidos enquanto categorias negativas e destruidoras da vida social. No entanto, era isso o que Marx havia feito no núcleo de sua crítica da economia política, tal como a desenvolveu, sobretudo na primeira seção d'O Capital. Para o movimento operário, para seus porta-vozes e seus intelectuais, o valor e o dinheiro, o trabalho e a mercadoria não mais constituíam categorias a serem abolidas, mas elementos naturais de toda vida humana, dos quais era preciso apropriar-se para administrar "diferentemente". Assim também, a produção industrial, inclusive seu ritmo e consequências para a vida humana e para a natureza não era considerada um problema, mas um recurso do qual se queria tirar proveito. Essa atitude chegava ao ponto de elogiar o fordismo, com sua linha de montagem e sua férrea disciplina, elogio pronunciado por Lênin e Gramsci em alguns de seus textos. Portanto, tratava-se essencialmente de dar continuidade ao capitalismo industrial, baseado no trabalho abstrato e na dupla 
natureza da mercadoria - abstrata e concreta -, mudando somente a propriedade jurídica dos meios de produção.

Neste texto, ao contrário, nos propomos a examinar o problema da alienação e da reificação, a partir das análises marxianas do fetichismo da mercadoria e do trabalho abstrato.

\section{Alienação e reificação: história, problemas e declínios teóricos}

Nesse contexto, os primeiros teóricos a retomar o conceito de alienação tiveram igualmente o grande mérito de colocar novamente a questão do conteúdo da produção capitalista, e não somente da distribuição de seus frutos. Seria interessante fazer um estudo estátistico das ocorrências do termo "alienação" na história do marxismo. Certamente seria possível descobrir que o termo esteve mais ou menos ausente dos discursos marxistas anteriores aos anos 1920; o que pode ser explicado também pela raridade de sua ocorrência nas obras de Marx até então conhecidas $^{1}$ e pelo fato de que ele parecia fazer parte dos vestígios de uma terminologia hegeliana. A primeira retomada importante do conceito de alienação teve lugar com a publicação de História e consciência de classe, de Georg Lukács, em 1923: ali, entretanto, o conceito de "alienação" se achava amplamente substituído pelo de "reificação". A palavra "alienação", no sentido marxiano, estava tão pouco presente no debate geral que, nos anos 1930, Henri Lefebvre - aliás, autor em 1936 de La conscience mystifiée $e^{2}$ um dos primeiros livros a examinar tais conceitos na

1 É preciso lembrar que os Manuscritos de 1844 e A ideologia alemã somente foram publicadas em 1932, e os Grundrisse, em 1939.

2 Henri Lefebvre e Norbert Guterman. La conscience mystifiée. Paris: Syllepse, 1999 [ $1^{\text {a }}$ ed. 1936]. 
França - viu-se, ao final de uma conferência sobre a "alienação", na situação de responder à seguinte pergunta: "Mas então você quer dizer que somos todos loucos?"”

O conceito de "alienação" conheceu ampla difusão após a Segunda Guerra Mundial. Sobretudo, nos anos 1960-1970, ele se propagou para muito além dos meios marxistas em sentido estrito. Ele parecia representar uma possibilidade de dar continuidade à crítica do capitalismo, apesar do fim da pobreza de massa e do que então se denominava frequentemente a "integração do proletariado" na sociedade capitalista e sua pretensa absorção nas "classes médias"4. Se a sociedade burguesa havia conseguido finalmente dar a cada um um pedaço de pão, dizia-se, nem por isso ela havia conseguido criar as condições para uma vida satisfatória, na qual os indivíduos podiam decidir sobre sua vida por si mesmos. Essa mudança na crítica social - em outras palavras, a passagem do "paradigma da exploração" ao "paradigma da alienação" resumia-se numa frase bem conhecida, aquela com a qual, em 1967, o situacionista Raoul Vaneigem abria o seu Traité du savoirvivre à l'usage des jeunes générations [A arte de viver para as novas gerações]: "Não queremos um mundo em que a garantia de não morrer de fome seja trocada pelo risco de morrer de tédio"s. Sabe-se que esse livro simbolizou, como poucos, a experiência da geração que logo mais, em maio de 1968, iria sair às ruas.

O "sucesso" do conceito de alienação comportava,

3 Henri Lefebvre. Le temps des méprises. Paris: Stock, 1975.

4 Permitiria criticar, igualmente, a realidade social na União Soviética: além da questão de saber se se tratava de um "Estado operário" ou não, em todo caso, era fácil demonstrar que a sociedade soviética não estava desprovida de "alienações". 5 Raoul Vaneigem. Traité de savoir-vivre à l'usage des jeunes générations. Paris: Gallimard, 1967, p. 5. [A arte de viver para as novas gerações. São Paulo: Conrad, 2002.] 
evidentemente, uma notável ampliação da crítica do capitalismo, visando, agora, bem mais do que apenas a denúncia da exploração econômica. Essa ampliação estava plenamente de acordo com os novos dados sociais, econômicos e políticos dos anos 1960, quando temas tradicionais como a "miséria operária" pareciam corresponder cada vez menos à realidade empírica. Quase todas as teorias sociais da época partiam do pressuposto de que o capitalismo havia resolvido o seu problema básico, identificado com a "anarquia do mercado" e com a pobreza engendrada por ela. A sociologia oficial e universitária tirava a conclusão de que o capitalismo - domesticado como "economia democrática de mercado" - constituía um horizonte insuperável, que certamente poderia ser melhorado, mas não abolido. As teorias sociais que, ao contrário, continuavam a expor a exigência de uma mudança radical, partiam da convicção de que o capitalismo não mais conheceria graves crises econômicas que pudessem desembocar em revoluções; concentravam toda a sua atenção na insatisfação dos indivíduos, na impossibilidade de controlarem suas condições de trabalho e suas vidas em geral. A esperança de que pudesse produzir-se "apesar de tudo" uma ação revolucionária dependia dessa insatisfação. A Escola de Frankfurt, a revista Socialisme ou Barbarie, a Internacional situacionista e certas obras de Henri Lefebvre estão entre as mais conhecidas expressões dessa abordagem. $\mathrm{O}$ conceito de alienação, porém, transbordava de seu quadro marxista para tornar-se um lugar-comum. Chegou a ser retomado por Martin Heidegger $^{6}$ e por sua escola, assim como por teólogos.

6 Em 1947, em sua Carta sobre o humanismo, Heidegger (nada oportunista naquele 
No entanto, o conceito de alienação, assim vulgarizado, apresentava ao menos três dificuldades que, aliás, os seus adversários não deixavam de explorar?

Antes de tudo, o termo (notadamente nas diferentes variantes de existencialistas e teólogos que dele se apoderavam) era empregado frequentemente de maneira bastante imprecisa, terminando por indicar simplesmente o mal-estar produzido pela sociedade industrial e pelo fato de sentir-se "estrangeiro" no mundo moderno.

Em seguida, na própria palavra alienação, assim como em seu equivalente "extrusão" (Entäußerung de que fala Hegel), encontra-se, linguisticamente, uma aversão pelo que é "estrangeiro", ou "de fora". Em alemão, Entfremdung (alienação) soa quase como Überfremdung (perder o seu caráter próprio por causa da presença maciça de estrangeiros, e sobretudo de um povo - é uma palavra típica do discurso racista na Alemanha). Por outro lado, na crítica da "reificação" ou "coisificação" (Verdinglichung)

momento!) afirmava que a filosofia marxiana da história é a "mais profunda", porque baseada no conceito de alienação, que ele gostaria vincular a seu conceito de "esquecimento do ser". É assim que Lucien Goldmann e outros trataram de demonstrar que o autor de Ser e tempo teria sofrido a influência de História e consciencia de classe. Mesmo que fosse verdade, entretanto, pode-se duvidar do interesse dessa questão.

7 Ainda assim, não havia unanimidade em torno do conceito de alienação. Os marxistas mais "ortodoxos" viam nele apenas uma diversão da luta de classes, um problema pequeno-burguês, tagarelice ou pretexto para desviar-se da luta social e limitar-se a lamentar a "dominação das coisas sobre os homens". Outros sequer compreendiam o termo: na obra de um marxista italiano - que, para o cúmulo da ironia, se chamava Armando Plebe, e, em seguida, passou para a extrema direita -, a afirmação segundo a qual o problema principal seria a "alienação do proletariado" fora alterada - o tipógrafo, sem dúvida, acreditou no erro - para a afirmação de que o problema principal era a "alimentação do proletariado". 
parece despontar uma forma de aversão pelas "coisas" (res) enquanto tais, pelo próprio mundo material, expressa em nome de um puro subjetivismo. Assim, a promoção desses dois termos exprimiria, indiretamente e cada qual à sua maneira, uma forma de narcisismo que tende a reduzir toda coisa a si mesma, assimilarse aos outros, assim como ao mundo exterior inteiramente. Nisso também se pode ler um tipo de vitalismo que identifica a vida com o movimento e com o devir, opondo-a a todas as fixações. $\mathrm{O}$ próprio Lukács denunciou essa atitude em seu préfacio autocrítico à reedição de História e consciência de classe, em $1967^{8}$. Traços dessa concepção vitalista de alienação encontram-se igualmente em situacionistas e obreiristas.

Ambos os aspectos do conceito de alienação, tal como foi propagado nos anos 1960 - seu caráter impreciso e o desejo implícito de salvaguardar a identidade do sujeito -, foram criticados eficazmente por Teodor W. Adorno, notadamente no pequeno capítulo "Objetividade e reificação", da Dialética negativa ${ }^{9}$. Esse gênero de objeções concerne sobretudo ao uso impróprio do conceito, assim como às suas possíveis derivações. Não se poderia aplicá-las ao conceito originário, tal como ele se encontra no jovem Marx.

Quanto à terceira objeção, ela visa o conceito de alienação enquanto tal: ele pressuporia uma essência originária que o

8 Georg Lukács. Histoire et conscience de classe [1923]. Tradução K. Axelos e J. Bois. Paris: Editions de Minuit, 1960. A edição de 1984 contém o prefácio acrescentado por Lukács à reedição alemã de 1967. [História e consciência de classe. São Paulo: WMF Martins Fontes, 2012.]

9 Theodor W. Adorno. Dialectique négative [1966]. Paris: Payot, 1992, pp. 231234. [Dialética negativa. Tradução Marco Antônio Casanova. Rio de Janeiro: Zahar, 2009.] 
homem teria perdido. Nos Manuscritos de 1844, Marx teria oposto o sujeito, enquanto Gattungswesen ("essência genérica"), a suas objetivações infiéis que não mais the pertencem e nas quais ele não pode se reconhecer, mas que, ao contrário, o dominam. A teoria primeira da alienação em Marx seria, portanto, uma "antropologia" que opõe uma natureza "verdadeira" do ser humano aos seus desacertos. Desse modo, tal teoria compartilharia os defeitos que caracterizam todas as teorias do sujeito assim como as abordagens "humanistas", e foi rejeitada pelos estruturalistas ${ }^{10}$.

No prolongamento dessas críticas, o conceito de alienação continuou a periclitar no período do pós-modernismo teórico que, como se sabe, se caracteriza sobretudo por seu anti-essencialismo declarado. O progressivo abandono é descrito por um de seus protagonistas, Jean Baudrillard, como segue:

A virtualidade é algo distinto do espetáculo, que ainda reservava lugar a uma consciência crítica e a uma desmistificação. A abstração do 'espetáculo', inclusive nos situacionistas, nunca se dava sem apelo. Ao passo que a própria realização condicional era inapelável [...]. Enquanto podíamos enfrentar a irrealidade do mundo como espetáculo, estamos indefesos diante da extrema realiade deste mundo, diante dessa perfeição virtual. Estamos, de fato, além de toda desalienação. ${ }^{11}$

Baudrillard, por sua vez, define assim o seu próprio percurso:

10 Cf., notadamente, Louis Althusser. "Marxisme et humanisme". In: Pour Marx. Paris: Maspéro, 1965.

11 J. Baudrillard. Le Crime parfait. Paris: Galilée, 1995, pp. 49-50. [O crime perfeito. Lisboa: Relógio d'água, 1997.] 
Num primeiro tempo, a simulação, a passagem generalizada ao código e ao valor-signo, é descrita em termos críticos, à luz (ou à sombra) de uma problemática da alienação. Através de argumentos semiológicos, psicanalíticos e sociológicos, é a sociedade do espetáculo que ainda está em causa, assim como a sua denúncia. A subversão ainda é buscada na transgressão das categorias da economia política: valor de uso, valor de troca, utilidade, equivalência. Os referentes dessa transgressão serão a noção de dispêndio em Georges Bataille e a de troca-dom em Marcel Mauss, o consumo e o sacrifício, ou seja, uma versão ainda antropológica e antieconomicista, onde a crítica marxiana do capital e da mercadoria se generaliza numa crítica antropológica radical dos postulados de Marx. Em Troca simbólica e a morte, essa crítica vai além da economia política. ${ }^{12}$

Baudrillard tem toda razão neste ponto: para poder denunciar a "alienação", é preciso indicar igualmente realidades que não são alienadas - realidades "autênticas" - em relação às quais a alienação (ou o "inautêntico") pode ser definida como tal. E é verdade que, a partir dos anos 1970, numa sociedade cada vez mais "unidimensional" (Marcuse) e esmagada por um "excesso de realidade" (Annie Le Brun) ${ }^{13}$, tornava-se difícil fazer a experiência de algo que pudesse ser oposto à alienação. $\mathrm{O}$ círculo parecia, a partir de então, bem fechado: nada mais havia senão a circulação

12 J. Baudrillard. L'Autre par lui-même. Habilitation. Paris: Galilée, 1987, pp. 67-68.

13 Herbert Marcuse. L'Homme unidimensionnel [1964]. Trad. M. Wittig. Paris: Éditions de Minuit, 1968. [A ideologia da sociedade industrial. Trad. Giasone Rebuá. Rio de Janeiro: Zahar, 1969.] Annie Le Brun. Du trop de réalité. Paris: Stock, 2000. 
entre diferentes formas de alienação, a qual se via reconduzida, assim, ao título de condição insuperável da pós-modernidade. Mas os que o afirmavam, como o próprio Baudrillard, já não se propunham a libertar o pensamento crítico dos limites que pudessem derivar de sua imbricação numa filosofia não superada do sujeito. Estavam, apenas, demasiado felizes em poder declarar que a própria distinção entre alienação e desalienação estava, de agora em diante, obsoleta.

\section{A centralidade do fetichismo da mercadoria}

Assiste-se, nos últimos anos, a tentativas de retomada dos conceitos de alienação e de reificação ${ }^{14}$. Claro, nesse meio tempo, o discurso sobre a alienação não havia desparecido inteiramente. O seu eclipse, porém, vinha acompanhado pela difusão de outro conceito de Marx que de certa maneirao prolonga: o "fetichismo da mercadoria". Aqui também um trabalho de estatística semântica se mostraria interessante. Mesmo em autores pertencentes ao marxismo crítico, tal conceito era bem raro antes dos anos 1970. Por exemplo, nas mil páginas de A teoria da alienação de Marx, do lukacsiano István Mészáros ${ }^{15}$, publicado em 1970 e ainda considerado um clássico no assunto, a palavra "fetichismo" praticamente nunca aparece. O subcapítulo sobre "O fetichismo da mercadoria e seu segredo", que encerra o primeiro capítulo d'O Capital, era então considerado como uma digressão tão

14 Para citar apenas dois autores: Axel Honneth. La Réification: petit traité de théorie critique, Gallimard, Paris, 2007 [edição original, 2005]. E Stéphane Haber. L'aliénation. Vie sociale et expérience de la dépossession. Paris: PUF, 2007.

15 István Mészaros. Marx's Theory of Alienation. Londres: Merlin Press, 1970. [A teoria da alienação em Marx. Tradução Isa Tavares. São Paulo: Boitempo, 2006.] 
incompreensível quanto inútil, uma recaída no hegelianismo, um capricho metafísico. Sempre é preciso lembrar que, em 1969, Louis Althusser queria proibir os leitores d'O Capital de começar pelo primeiro capítulo - no qual se inscreve a passagem sobre o fetichismo da mercadoria -, julgando-o difícil demais. $\mathrm{O}$ argumento de Althusser consistia em afirmar que os leitores, para melhor compreender $O$ Capital, deveriam perceber o conflito visível entre trabalho vivo e trabalho morto como ponto de partida e "pivô" da crítica marxiana, e considerar a análise da formavalor, com a qual se abre $O$ Capital, somente como uma precisão suplementar, a ser aprofundada num segundo momento. $\mathrm{O}$ que Athusser escreveu em seu prefácio a uma edição d'O Capital merece ser reportado:

As maiores dificuldades teóricas, além de tantas outras, que constituem obstáculo a uma leitura fácil do livro I d'O Capital, estão, infeliz (ou felizmente) concentradas no próprio início do livro I, mais precisamente em sua seção I, que trata de 'A mercadoria e a moeda'. Dou então o seguinte conselho: colocar PROVISORIAMENTE ENTRE PARÊNTESES TODA A SEÇÃO I e COMEÇAR A LEITURA PELA SEÇÃO II: 'A transformação do dinheiro em capital'. A meu ver, só é possível começar (e somente começar) a compreender a seção I, após ter lido e relido todo o livro I a partir da seção II. Este conselho é mais do que um conselho: é uma recomendação que, com todo o devido respeito a meus leitores, eu me permito apresentar como uma recomendação imperativa. Cada um poderá fazer a experiência prática disso. Se se começar a ler o livro I por seu começo, isto é, pela seção I, ou ele não é compreendido, ou ele é abandonado; ou 
acredita-se compreendê-lo, o que é ainda mais grave, pois há grandes chances de ter compreendido outra coisa do que se deveria compreender. ${ }^{16}$

"Recomendação imperativa" - percebe-se bem o despeito do teórico por não ter o poder do qual dispunham os seus colegas russos ou chineses: enviar para a Sibéria, ou para um campo de reeducação, aqueles que ousavam ler aquilo que, entretanto, lhes fora proibido ler.

Sabe-se que as proibições produzem, em geral, o efeito contrário. Decerto, para os marxistas que se queriam "ortodoxos", tal conceito descrevia somente um epifenômeno. "Segundo Jacques Bidet, a noção de fetichismo da mercadoria se contenta em designar a defasagem existente entre a representação espontânea dos agentes e as relações reais"17, escreve Antoine Artous, o qual lembra igualmente que o Dicionário crítico do marxismo, publicado em 1982, só consagra pouquíssimo espaço à noção de fetichismo ${ }^{18}$. Apesar desse bloqueio, o termo conheceu crescente difusão no interior da crítica do capitalismo, ao menos em suas formas mais refletidas.

Se atualmente as referências ao termo "fetichismo" se tornaram mais frequentes, todavia elas não são acompanhadas de aprofundamento. Assim como o termo "sociedade do espetáculo", o "fetichismo da mercadoria" parece resumir a baixo custo as

16 Louis Althusser. "Préface" a Karl Marx. Le Capital. Paris: Flammarion, 1969, p. 13. Itálicos e maiúsculas estão no original.

17 Antoine Artous. Le Fétichisme chez Marx. Le marxisme comme théorie critique. Paris: Syllepse, 2006 , p. 46. O autor remete a Jacques Bidet. Théorie de la modernité. Paris: Presses Universitaires de France, 1990, p. 230.

18 Antoine Artous, Le Fétichisme chez Marx, op. cit., p. 74. 
características de um capitalismo pós-moderno que supostamente voltou-se essencialmente para o consumo, a publicidade e a manipulação dos desejos. Certo uso popular da palavra, influenciado principalmente por seu uso em psicanálise, nela enxerga somente um amor excessivo das mercadorias e a adesão aos valores que elas representam (velocidade, sucesso, beleza etc.).

Claro, os intelectuais marxistas não cairão em tais ciladas. Mas quase todos compartilham uma concepção do fetichismo da mercadoria que é igualmente muito redutora. Segundo a opinião predominante, Marx designava por esse termo uma "ideologia espontânea" que essencialmente teria por meta velar o fato de que o sobrevalor tem sua origem exclusivamente no trabalho não pago do operário. Assim, o fetichismo constituiria um engodo ou uma mistificação e participaria da autojustificação da sociedade capitalista. Entretanto, o que é exatamente esse conceito em Marx?

Por vezes Marx utiliza efetivamente o termo fetichismo naquele sentido. É notadamente o caso num fragmento sobre a "fórmula trinitária" que Friedrich Engels colocou na parte final do livro III d'O Capital (cuja montagem ele atestou), parte na qual Marx evoca a "personificação das forças produtivas" e o "mundo encantado" onde passeiam o "Senhor Capital" e a "Senhora Terra"19. Entretanto, o fetichismo que está em questão ali não é verdadeiramente o mesmo fetichismo analisado no primeiro capítulo d'O Capital. Trata-se, mais precisamente, de dois diferentes níveis de análise, que não se contradizem. $\mathrm{O}$ itinerário seguido n' $O$ Capital conduz, com efeito, da essência à

19 Karl Marx, Le Capital. Critique de l'économie politique, vol. III, tr. C. CohenSolal et G. Badia. Paris: Editions Sociales, 1976, p. 915. [O capital. Tradução Rubens Enderle. São Paulo: Boitempo, 2013.] 
aparência, da crítica categorial à análise da superfície empírica, das categorias puras às formas concretas que tais categorias assumiam naquela época. O caso paradigmático é o percurso que leva do "valor" - categoria não-empírica -, através de numerosas etapas intermediárias, até o "preço de mercado", que constitui o único nível imediatamente perceptível pelos atores econômicos e objeto quase exclusivo da ciência econômica burguesa. Assim também, os dois desenvolvimentos maiores de Marx sobre o fetichismo ${ }^{20}$ correspondem, um deles à essência, e o outro, à forma fenomenal. Após a longa e meticulosa descrição das relações que se mantêm entre o linho e o casaco, o café e o ouro - e que já contêm "em germe", como ele mesmo o diz, toda a crítica do capitalismo! -, antes de introduzir, no início do segundo capítulo, os seres humanos enquanto "guardiães" das mercadorias que "não podem ir por si mesmas ao mercado" 21 , Marx intercala, como uma aparente digressão, o capítulo sobre o caráter fetichista das mercadorias. Mas o próprio lugar do fetichismo da mercadoria na engenhosa arquitetura da obra de Marx sugere que este capítulo toca no coração de toda a sua crítica do capital: se a análise da dupla

20 É preciso acrescentar outras ocorrências da palavra fetichismo em quase todas as obras de crítica da economia política de Marx, sem contar as passagens nas quais o fetichismo está em questão sem que a palavra apareça explicitamente. É forçoso admitir que todas as considerações marxianas sobre o fetichismo são fragmentárias e difíceis de compreender, tanto em razão do recurso a metáforas quanto devido à dificuldade efetiva de descrever um fenômeno que, antes de Marx, ninguém se havia aventurado a explorar.

21 Karl Marx, Le Capital. Critique de l'économie politique, Livre I: Le procès de production du capital ; obra publicada sob a responsabilidade de Jean-Pierre Lefebvre. Paris: PUF, 1993 ; p. 96. [O capital. Tradução Rubens Enderle. São Paulo: Boitempo, 2013.] Seria possível dizer que toda a problemática do fetichismo se encontra nessa frase irônica sobre o fato de que os homens só entram em cena para servir as mercadorias, as quais são os verdadeiros atores desse processo. 
natureza da mercadoria e da dupla natureza do trabalho constitui, para dizê-lo com as palavras de Marx, o "pivô" (Springpunkt) de sua análise ${ }^{22}$, o capítulo sobre o fetichismo faz parte desse núcleo. $\mathrm{O}$ fetichismo não é um fenômeno pertencente apenas à esfera da consciência, não está limitado à ideia que os atores sociais fazem de suas próprias ações - nesse estágio inicial de sua análise, Marx não se preocupa em saber como os sujeitos percebem as categorias de base e a elas reagem. O fetichismo, portanto, faz parte da realidade básica do capitalismo; é a consequência direta e inevitável da existência da mercadoria e do valor, do trabalho abstrato e do dinheiro. A teoria do fetichismo é idêntica à teoria do valor, porque o valor, assim como a mercadoria, o trabalho abstrato e o dinheiro são, eles próprios, categorias fetichistas.

Por que o fetichismo é um fenômeno real? A sociedade em que os produtos do trabalho tomam a forma mercantil é "uma formação social onde é o processo social que domina os homens, e não ainda o inverso"23. Como acabamos de dizer, o subcapítulo sobre o fetichismo não é um simples apêndice: dele, Marx tira as conclusões de sua análise precedente da forma-valor. Nele, as categorias de base já são descritas como fetiches, mesmo se a palavra "fetichismo" não aparece ali. Sempre é preciso lembrá-lo: Marx não "define" tais categorias como pressupostos neutros, como o fazia David Ricardo e como fariam os marxistas posteriores $^{24}$. Ele denuncia, desde o início da análise, o seu caráter

$22 \mathrm{Ibid}$, p. 47: "Fui o primeiro a apontar, de maneira crítica, essa natureza bífida do trabalho contido na mercadoria. Como é em torno deste ponto que gira toda a compreensão da economia política, convém, aqui, esclarecê-lo um pouco mais". $23 \mathrm{Ibid}$, p. 93.

24 Amiúde são qualificados, justamente, como "socialistas ricardianos": aceitam, com efeito, a concepção ricardiana do "valor-trabalho" e de uma eterna "lei do valor", 
negativo e destruidor - não acrescentando um juízo "moral" a um desenvolvimento "científico", mas ressaltando a negatividade de sua própria análise. Ele põe em relevo uma inversão constante entre o que deveria ser o elemento primeiro e o que deveria ser o derivado, entre o abstrato e o concreto. A primeira particularidade da "forma-equivalente", aparentemente tão inocente ("20 braças de linho valem dois casacos"), é a seguinte: nela, o valor de uso se torna a "forma fenomenal" de seu contrário, o valor. O mesmo ocorre em seguida para o trabalho: "Há, portanto, uma segunda característica da forma-equivalente: o trabalho concreto torna-se a forma fenomenal de seu contrário, do trabalho humano abstrato" 25 . E finalmente "há, portanto, uma terceira característica da forma-equivalente: o trabalho privado torna-se a forma de seu contrário, torna-se trabalho sob uma forma imediatamente social" 26 . Em outros termos: a forma-valor universal "manifesta assim que, no seio desse mundo das mercadorias, é o caráter universalmente humano do trabalho que constitui o seu caráter especificamente social" ${ }^{27}$.

Estamos diante do coração do problema: ali onde os indivíduos só se encontram enquanto produtores separados que devem reduzir os seus produtos a uma medida comum - que os priva de toda qualidade intrínseca - para poder trocá-las e formar uma sociedade, o valor, o trabalho humano abstrato e o trabalho "universalmente humano" (isto é, não específico, não social, o puro dispêndio de energia sem relação com os seus conteúdos e

que simplesmente se trataria de "aplicar", segundo princípios de justiça social.

25 Marx, Le Capital, op. cit., p. 67.

26 Marx, Le Capital, op. cit., p. 67.

27 Marx, Le Capital, op. cit., p. 67. 
consequências) sobrepujam o valor de uso, o trabalho concreto e o trabalho privado. Os homens, mesmo continuando a executar trabalhos concretos e privados, devem constatar que a outra "natureza" desses mesmos trabalhos, o lado abstrato, é o único que conta a partir do momento em que quiserem trocá-los contra algo distinto. Por exemplo, o camponês que trabalhou o dia inteiro para colher o seu trigo, como ele sempre o fez, poderia constatar no mercado que a sua jornada de trabalho concreto e privado subitamente "vale" apenas duas horas de trabalho, porque importações de trigo, provenientes dos países onde esse tipo de trabalho é mais "produtivo", estabeleceram um novo padrão - e, assim, o lado "abstrato" se torna terrivelmente real para esse camponês que cai na miséria.

Nesse estágio da demonstração - portanto, na análise da formavalor -, ainda não estão em questão nem o capital e o salário, nem a força de trabalho e a propriedade dos meios de produção. Supondo implicitamente a sua existência (porque a ordem lógica da exposição não coincide com a ordem histórica, e a mercadoria, sendo a "célula germinal" do capital, só existe em sua forma completa num regime capitalista), Marx, no plano lógico, as deduz das categorias anônimas mercadoria e trabalho abstrato, valor e dinheiro.

No seu nível mais profundo, o capitalismo não é, portanto, a dominação de uma classe sobre a outra, mas o fato, sublinhado pelo conceito de fetichismo da mercadoria, de que toda a sociedade está dominada por abstrações reais e anônimas. Há grupos sociais que administram esse processo e dele extraem benefícios - porém, chamá-los "classes dominantes" significaria tomar as aparências por "dinheiro vivo". Marx não diz outra coisa quando denomina o valor de "sujeito automático"28 do capitalismo.

28 Ibid, p. 173. Nos Grundrisse, Marx escreve: “O valor se apresenta como sujeito.” 


\section{Fetichismo, alienação e reificação: reconstruir uma continuidade teórica}

No interior do marxismo crítico, a temática do fetichismo foi por vezes considerada como uma espécie de alternativa à da alienação. Dois autores franceses que se debruçaram com a maior seriedade sobre o conceito de fetichismo, Jean-Marie Vincent ${ }^{29} \mathrm{e}$ Antoine Artous ${ }^{30}$, insistem neste ponto: enquanto o conceito de alienação permaneceria petrificado nas aporias que caracterizam toda filosofia do sujeito e cairia na antropologização e na ontologização da dialética do sujeito e do objeto, o conceito de fetichismo analisaria as relações sociais que se criam efetivamente na sociedade capitalista.

Ambos os autores sublinham justamente que o conceito marxiano de fetichismo não está vinculado a uma dialética do sujeito e do objeto, nem a uma ocultação das "verdadeiras" relações de produção, mas, antes, que ele traduz a realidade do trabalho abstrato. No entanto, mesmo admitindo que o fetichismo não é uma simples ilusão, Antoine Artous o define como uma das "representações" que "acompanham e estruturam" a relação social $^{31}$. Para compreender que o fetichismo é uma "inversão real", primeiramente é preciso se dar conta de que o trabalho abstrato não é uma abstração nominal, nem uma convenção que

(Karl Marx. Manuscrit de 1857-1858 (Grundrisse). Paris: Éditions Sociales, 1980, p. 250.) [Grundrisse manuscritos econômicos de 1857-1858. Trad. Mario Duayer. São Paulo: Boitempo, 2011.]

29 Na França, Jean-Marie Vincent foi, sem dúvida, o pioneiro nesse campo com Fétichisme et société (Paris: Anthropos, 1973) e Critique du travail (Paris: PUF, 1987). 30 Antoine Artous, Le Fétichisme chez Marx, op. cit. 31 Ibid, p. 21. 
nasce (ainda que inconscientemente) na troca: ele é a redução efetiva de toda atividade a um simples dispêndio de energia. Tal redução é "efetiva" na medida em que as atividades particulares - assim como os indivíduos que as realizam - só se tornam sociais enquanto reduzidas a essa abstração. Se a consideração do fetichismo conheceu alguns avanços nos últimos anos, a temática do trabalho abstrato - o "coração das trevas" do modo de produção capitalista - e a crítica da ontologização do trabalho permanecem, pelo contrário, como um continente a ser descoberto. Quando a categoria do fetichismo é compreendida somente como uma mistificação das "relações reais" de exploração, a (peudo)crítica do fetichismo chega mesmo a ser expressa, de maneira absurda, em nome do "trabalho" que o fetichismo "ocultaria" -, ao passo que, na realidade, nenhuma superação do fetichismo é possível sem abolir praticamente o trabalho como princípio de síntese social.

Mas se o fetichismo consistir de fato nessa inversão real, ele não será tão diferente da alienação de que falava Marx em seus primeiros textos. Inversamente, argumentos como os de Jean-Marie Vincent e Antoine Artous reintroduzem curiosamente o "corte epistemológico" - que, no entanto, tais autores recusam justamente em sua forma althusseriana - entre um jovem Marx, filósofo humanista, e um Marx da maturidade, convertido à ciência. Ainda assim, eles cortam quase todo vínculo entre o fetichismo e a crítica da religião no jovem Marx - embora, desde a origem do termo "fetichismo", assim como a sua presença na primeira publicação de $\mathrm{Marx}^{32}$, dão testemunho de tal continuidade. Antoine

32 Karl Marx, Les délibérations de la Sixième Diète rhénane. Les débats sur la loi relative aux vols de bois (1842). In: Karl Marx, Euvres, vol. III - Philosophie. Paris: Gallimard, "Pléiade", 1982 ; p 280. 
Artous assegura que a mercadoria, diferentemente de um deus, é "real" 33 . Nisso, porém, ele se esquece de que a mercadoria só é "real" enquanto valor de uso. O fato de lhe atribuir um "valor", isto é, de tratá-la segundo o trabalho (passado, ausente) que foi necessário para a sua produção - embora o trabalho passado já não esteja mais aí - e, sobretudo, de considerá-la não segundo o trabalho que foi dispendido real e individualmente, mas enquanto parte do trabalho social global (o trabalho socialmente necessário para a sua produção), resulta de uma "projeção" não menor do que aquela que tem lugar na religião. O produto só se torna mercadoria porque uma relação social ali se representa - e essa relação social é tão "fantasmagórica" (no sentido de não fazer parte da natureza das coisas) quanto um fato religioso.

Naturalmente, a mercadoria não ocupa exatamente o mesmo lugar que Deus na vida social. Mas Marx sugere - eis porque se pode falar de uma continuidade propriamente conceitual entre as noções de alienação e de fetichismo em Marx - que o fetichismo da mercadoria é a continuação de outras formas de fetichismo social, como o fetichismo religioso. $\mathrm{O}$ "desencantamento do mundo" ou a "secularização" não tiveram lugar verdadeiramente: a metafísica não desapareceu com as Luzes, mas desceu do Céu e se mesclou à realidade terrestre. É o que Marx diz quando denomina a mercadoria um "ser sensível-suprassensível" ${ }^{34}$.

As três inversões que Marx descreve em sua análise da forma-valor são inversões entre o concreto e o abstrato. O que deveria estar em primeiro lugar, o trabalho concreto, o valor de uso, torna-se um derivado daquilo que deveria ser o derivado

33 Antoine Artous, Le Fétichisme chez Marx, op. cit., p. 25. 34 Marx, Le Capital, op. cit., p. 81. 
do concreto: o trabalho abstrato. Em termos filosóficos, seria possível falar de uma inversão entre a substância e o acidente. A descrição que Marx oferece da alienação nos Manuscritos de 1844 não aparece, portanto, como uma abordagem fundamentalmente diferente da conceitualização do fetichismo, mas como uma primeira aproximação, uma abordagem ainda limitada, que já dizia, implicitamente, o essencial: a despossessão do homem pelo trabalho abstrato que se tornou o princípio da síntese social.

Apesar da importância da temática marxiana do "trabalho abstrato" na teoria lukacsiana da reificação, é preciso sublinhar que a sua retomada em História e consciência de classe apresenta sérios problemas. Mesmo por ocasião de seu prefácio, na reedição de 1967, no qual aponta as fraquezas de sua obra escrita quarenta e cinco anos antes, Lukács não se mostra consciente do fato de que havia confundido o trabalho abstrato com o trabalho racionalizado, parcializado, padronizado. O importante desenvolvimento deste último na época de História e consciência de classe - fruto da aplicação da ciência e da tecnologia na produção capitalista, de que a cadeia de montagem era a expressão mais espetacular - constituía efetivamente uma consequência da penetração da lógica mercantil na sociedade. Mas o trabalho abstrato de que fala Marx, enquanto "forma social", não tem nada a ver com o conteúdo do trabalho, nem com os seus procedimentos técnicos. Cada trabalho produtor de mercadorias é, ao mesmo tempo, concreto e abstrato: o trabalho na cadeia de montagem não será "mais abstrato" que o trabalho de um artesão, se este último estiver inserido na produção capitalista. Seria mais claro, com efeito, falar de "lado" concreto e "lado" abstrato do mesmo trabalho, para evitar o mal-entendido segundo o qual seriam dois trabalhos diferentes.

A fusão operada por Lukács em História e consciência de classe entre o conceito marxiano de trabalho abstrato, o conceito weberiano de racionalização e os dados empíricos concernentes 
às transformações da grande indústria em sua época, de certa maneira, era genial. Ela permitia conectar diferentes níveis de análise, e sabe-se que influência tal abordagem exerceu durante quase um século, com um "pico" nos anos 1960. Mas constatar a sua importância e o seu papel inovador não deveria nos fazer esquecer que, hoje, a análise do trabalho abstrato deve em parte se libertar dessa influência, para distinguir rigorosamente entre a dupla natureza de todo trabalho no capitalismo (e que, enquanto tal, não está sujeita a mudança por causa da nova divisão do trabalho), de um lado, e, de outro lado, a evolução concreta das formas de trabalho. Essa evolução - a industrialização do trabalho - deriva, em última análise, da dupla natureza do trabalho, mas não é imediatamente idêntica a ela.

\section{$*$ \\ A "crítica do valor" (Wertkritik) ${ }^{35}$ situou a crítica do}

35 Esta corrente teórica se articulou, até agora, em torno das revistas alemãs Krisis (publicada desde 1987) e Exit! (publicada desde 2004), animadas sobretudo por Robert Kurz, e em torno da obra de Moishe Postone, professor em Chicago. Até agora, em francês, foram publicados: Anselm Jappe, Les Aventures de la marchandise. Pour une nouvelle critique de la valeur, Denoël, Paris, 2003[As aventuras da mercadoria. Lisboa: Antígona, 2013.]; Anselm Jappe, Guy Debord, Denoël, Paris, 2001[Guy Debord. Petrópolis-RJ:Vozes, 99]; Anselm Jappe, L'Avant-garde inacceptable, Lignes/ Manifestes, Paris 2004 ; Groupe Krisis, Manifeste contre le travail, Lignes/ Manifestes, Paris, 2002 (réédité par l'Union générale d'éditions, collection 10/18, Paris, 2004) [Grupo Krisis. Manifesto contra o trabalho. Trad. Heinz Dieter Heidemann. São Paulo: LABUR/Dep. Geografia/FFLCH /USP: Cadernos do LABUR, nº 2, jul. 1999 ]; 
Robert Kurz, Lire Marx. Les principaux textes de Karl Marx pour le XXI siècle, La Balustrade, Paris, 2002 ; Robert Kurz, Avis aux naufragés. Chroniques du capitalisme mondialisé en crise, Lignes/Manifestes, Paris, 2005 ; Robert Kurz, Critique de la démocratie balistique. La gauche à l'épreuve des guerres d'ordre mondial, Éditions Mille et une nuits, Paris, 2006 ; Anselm Jappe et Robert Kurz, Les Habits neuf de l'Empire. Remarques sur Negri, Hardt et Rufin, Lignes/ Manifestes, Paris, 2003; Moishe Postone, Temps, travail et domination sociale. Une réinterprétation de la théorie critique de Marx, Mille et une nuits, Paris, 2009 ; Moishe Postone, Face à la mondialisation, Marx est-il devenu muet?, L'Aube, Paris, 2003 ; Norbert Trenkle, "Négativité brisée. Remarques sur la critique de l'Aufklärung chez Adorno et Horkheimer", in Lignes, nouvelle série, $\mathrm{n}^{\circ} 11$, mai 2003 ; Dossier "Critique de la valeur, sexe et capitalisme", in Illusio, $n^{\circ} 4-5,2007$, contendo: Robert Kurz, "La femme comme chienne de l'homme", Anselm Jappe, "Sade, prochain de qui ?", Roswitha Scholz, "Remarques sur les notions de "valeur"et de "dissociation-valeur"“ et Johannes Vogele, "Le côté obscur du capital. "Masculinité" et "féminité" comme piliers de la modernité" ; Anselm Jappe, "Pourquoi lire Sohn-Rethel aujourd'hui", in Alfred Sohn-Rethel, La pensée-marchandise, Éditions du Croquant, Bellecombes-en-Bauges, 2009 ; Anselm Jappe, “Avec Marx, contre le travail” (compte rendu des ouvrages de M. Postone et de I. Roubine), in Revue Internationale des livres et des idées $\mathrm{n}^{\circ} 13$, septembre-octobre 2009. [Em português, destes autores citados, foram traduzidos ainda: Anselm Jappe. Violência, mas para quê ? São Paulo: Hedra, 2013 ; Anselm Jappe. Crédito à morte. São Paulo: Hedra, 2013 ; Anselm Jappe. Sobre a balsa da medusa. Trad. José Alfaro. Lisboa: Antígona, 2012 ; Anselm Jappe. Sic transit gloria artis. Lisboa: Centelha Viva, s.d. ; Robert Kurz. A razão sangrenta. São Paulo: Hedra, 2010 ; Robert Kurz. Dinheiro sem valor. Lisboa: Antígona, 2014 ; Robert Kurz. Os últimos combates. Petrópolis-RJ: Vozes, 1997 ; Robert Kurz. Com todo vapor ao colapso. Juiz de Fora: Ed. UFJF, 2004 ; Robert Kurz. O retorno de Potemkim. Rio de Janeiro: Paz e Terra, 1993 ; Robert 
fetichismo mercantil no centro de sua abordagem teórica. Ela é, também, uma crítica da alienação, mesmo se esta palavra está praticamente ausente dos escritos de Robert Kurz. Moishe Postone, em compensação, escreve que a sua "abordagem reinterpreta a concepção de alienação de Marx em relação à sua crítica do trabalho sob o capitalismo - situa essa concepção reinterpretada da alienação no coração de sua crítica do capitalismo"36. Ele recusa, entretanto, uma leitura da superação da alienação como auto-realização de um sujeito de que já se supõe a existência e que, por sua essência, se coloca fora do capitalismo; ao passo que, na verdade, tal sujeito não é senão o "sujeito automático" constituído pelo trabalho abstrato. Em sua perspectiva, é preciso antes: "abolir o Sujeito que se move e que funda a si mesmo (o capital) e a forma de trabalho que constitui e é constituída pelas estruturas da alienação; isso permitiria à humanidade apropriar-se daquilo que foi criado sob forma alienada" ${ }^{37}$. Para ele, é evidente que, "em Marx, o conceito de fetichismo está ligado de maneira central à sua teoria da alienação, enquanto constituição social"38.

Kurz. O colapso da modernização. Rio de Janeiro: Paz e Terra, 1993. Robert Kurz. "A ruptura ontológica". In: Maria Elisa Cevasco e Milton Ohata (Orgs.). Um crítico na periferia do capitalismo. São Paulo: Companhia das Letras, 2007. Roswitha Scholz. "O valor é o homem: teses sobre a socialização pelo valor e a relação entre os sexos". In: Novos estudos CEBRAP. São Paulo: nr. 45, julho/1996. Conferir também site português: http://obeco.planetaclix.pt/.]

36 Moishe Postone, Temps, travail et domination sociale. Une réinterprétation de la théorie critique de Marx, [1993]. Paris: Mille et une nuits, 2009 ; p. 242.

37 Ibid, p. 331.

38 Ibid, p. 331. 
O essencial, para Moishe Postone, é que Marx superou a sua concepção inicial da alienação enquanto alienação de um sujeito pressuposto que existiria independentemente de sua constituição capitalista, que seria constituído pelo trabalho - enquanto categoria atemporal - e deveria se reapropriar das objetivações sobre as quais ele perdera o controle. O Marx da maturidade, ao contrário, teria chegado à conclusão de que, no capitalismo, o sujeito e o objeto, desde o início, se desenvolveram em formas alienadas. Não há essência originária para reconquistar ou fazer triunfar, e, sobretudo, não há essência constituída por um trabalho transhistórico. A verdadeira "ruptura" na evolução das ideias de Marx se situa, antes, no fato de reconhecer uma alienação no próprio trabalho abstrato, e não somente na exploração do trabalho vivo. Esta última constitui, antes, uma consequência:

Se o ponto de partida é um conceito transhistórico de 'trabalho', a diferença entre alienação e objetivação se funda necessariamente em fatores exteriores à atividade objetivante por exemplo, nas relações de propriedade [...]. Nos escritos do Marx da maturidade, ao contrário, a alienação se enraíza no duplo caráter do trabalho determinado pela mercadoria e, enquanto tal, ela é inerente à própria natureza desse trabalho [...]. Marx mostra, antes, que a objetivação é efetivamente a alienação - pois aquilo que o trabalho objetiva, são as relações sociais. ${ }^{39}$

Assim, Postone inverte a distinção estabelecida por Lukács em sua autocrítica, já mencionada, de 1967. Nesta, o filósofo húngaro afirma que não faria sentido criticar a objetivação enquanto tal, porque assim se evocaria um sujeito-objeto idêntico, colocando o ideal de um sujeito que conteria nele mesmo todos

39 Ibid, p. 238. 
os objetos, como no idealismo hegeliano. Em compensação, a distinção entre objetivação e alienação que faltava em seu livro de 1923, acrescenta Lukács, estava bem presente nos Manuscritos de 1844. De certa maneira, Moishe Postone dá razão ao Lukács de 1923: num regime capitalista, em que o trabalho desempenha o papel de mediação social universal, toda objetivação da atividade humana num trabalho constitui efetivamente uma alienação. Formas de objetivação não alienantes podem, portanto, se constituir, mas somente numa sociedade pós-capitalista, onde o trabalho não será mais uma mediação social. Moishe Postone chega a essa conclusão porque recusa o estatuto ontológico e transhistórico do trabalho. Lukács, por sua vez, nunca teria aceitado esse questionamento do trabalho, nem em 1923, nem em 1967. Prova suplementar de que mesmo os marxistas mais críticos e mais dialéticos desse período permaneciam prisioneiros de uma ontologia do trabalho, e, por conseguinte, não lhes era possível apreender o cerne das categorias do fetichismo e da alienação. Foi preciso esperar a crise real e visível da sociedade do trabalho, uma crise que se instalou de maneira durável a partir dos anos 1970, para chegar à compreensão teórica do trabalho abstrato, e portanto, em última análise, do fetichismo da mercadoria. 